\title{
触 New Disease Reports \\ First report of Ceratocystis fimbriata causing wilt in Tectona grandis in Brazil
}

\author{
A.C. Firmino ${ }^{1}$, H.J. Tozze $\mathrm{Jr}^{2}$ and E.L. Furtado ${ }^{1}$ \\ ${ }^{1}$ Departamento de Produção Vegetal/Defesa Fitosanitária, Faculdade de Ciências Agronômicas, UNESP, Botucatu, SP \\ Brazil; ${ }^{2}$ Departamento de Fitopatologia/ESALQ-USP, Piracicaba, SP, Brazil \\ *E-mail: anacarfir@gmail.com
}

Received: 08 Oct 2011. Published: 21 May 2012. Keywords: teak, drought, fungal plant disease

Teak (Tectona grandis) is a species native to the wetlands of the Indian subcontinent and Southeast Asia. Currently, it is cultivated in almost al tropical regions. Teak was introduced to Brazil 80 years ago, into Mato Grosso (MT) among other states. MT has the largest planted area (about 50,000 hectares) with potential for future expansion due to its favourable climate. In September 2009, teak plants were found with wilt symptoms in the region of Cáceres, MT, Brazil. Stem fragments with characteristic symptoms were collected and placed on carrot baits (Moller \& DeVay, 1968 ) in a humid chamber and incubated at $25 \pm 2^{\circ} \mathrm{C}$ under an alternate 12 hour photoperiod. After perithecium formation, a portion of the ascospore mass was transferred to malt extract agar medium (MEA) to allow the formation of colonies which were incubated under the above-mentioned conditions. After 10 days, observed perithecia were black, globose (233.12 x $277.74 \mu \mathrm{m})$ and showed a long rostrum $(729 \mu \mathrm{m})$. Ascospores had the typical format of a "hat" with dimensions of $3.62 \times 4.68 \mu \mathrm{m}$ Chlamydospores $(10.76 \times 14.03 \mu \mathrm{m})$ and cylindrical endoconidia (19.89 x $3.12 \mu \mathrm{m}$ ) were observed (Fig. 1). Barrel-shaped endoconidia were not found. The morphological characteristics indicated that the isolate belonged to the species Ceratocystis fimbriata (Engelbrecht \& Harrington, 2005). The ITS1 and ITS4 sequenced region of the isolate (JQ354938) showed $98 \%$ similarity to the isolate of C. fimbriata strain CMW5312 (AF395687.1).

The inoculation of plants was performed according to Silveira et al (2006), with some modifications. One-centimetre mycelial discs of the fungus (from 10-day-old colonies on MEA) were placed onto the injured stems of six-month-old healthy teak plants. The inoculation site was

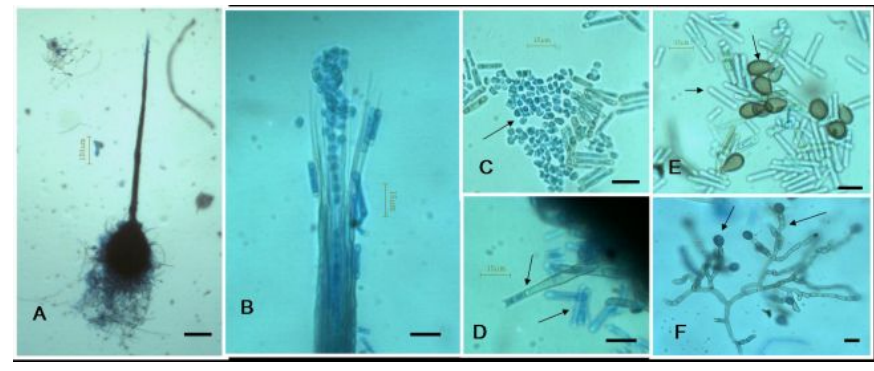

Figure 1 wrapped with cotton cloth (moistened with sterile distilled water) and plastic film. Some plants were inoculated with MEA disc as negative control. The inoculated plants were kept in greenhouse (average temperature of $27^{\circ} \mathrm{C}$ ). Wilt symptoms caused by $C$. fimbriata were observed 90 days after inoculation and plant death at 120 days (Fig. 2). The fungus was again isolated in culture from the stem of these inoculated teak plants, confirming the pathogenicity. This is the first report of $C$. fimbriata in teak in Mato Grosso, Brazil.

\section{Acknowledgements}

The authors would like to thank Dr. Daniel Dias Rosa, CNPq and Fapesp.

\section{References}

Engelbrecht CJB, Harrington TC, 2005. Intersterility, morphology and taxonomy of Ceratocystits fimbriata from sweet potato, cacao and sycamore. Mycologia 97, 57-69. [doi:10.3852/mycologia.97.1.57] Moller WJ, DeVay JE, 1968. Carrot as a species selective isolation medium for Ceratocystis fimbriata. Phytopathology 58, 123-124.

Silveira SF, Harrington TC, Mussi-Dias V, Engelbrecht CJB, Alfenas AC, Silva CR, 2006. Annona squamosa, a new host of Ceratocystis fimbriata. Fitopatologia Brasileira 31, 394-397.

[doi:10.1590/S0100-41582006000400010]

To cite this report: Firmino AC, Tozze Jr HJ, Furtado EL, 2012. First report of Ceratocystis fimbriata causing wilt in Tectona grandis in Brazil. New Disease Reports 25, 24. [doi:10.5197/j.2044-0588.2012.025.024]

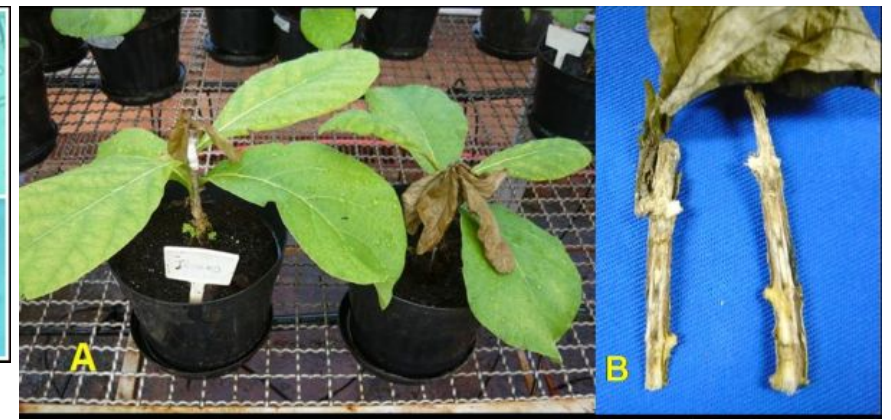

Figure 2 